\title{
Compatibilidad interfacial e interna en el compuesto fibra de cobre cemento
}

\section{Interface and internal compatibility in a copper fibre cement composite}

Fecha de recepción: 18-VI-93.

\author{
P. KITTL, G. DÍAZ y V. MARTINEZ \\ Departamento de Ingeniería de Materiales, IDIEM \\ Facultad de Ciencias Físicas y Matemáticas \\ Universidad de Chile, Casilla 1420, Santiago, Chile
}

\section{RESUMEN}

Este trabajo presenta el comportamiento mecánico de un compuesto fabricado por compactación y constituído por fibras de cobre distribuídas aleatoriamente en una matriz de cemento portland. Las muestras, la mitad con fibras y la otra sin ellas, se sometieron a fatiga por compresión. EI ciclo de carga fue de 1 hertz y la carga aplicada aquella correspondiente a la tensión asociada a un $1 \%$ de probabilidad de fractura cuando la carga se aplica gradualmente. Para ambos tipos de muestras se graficaron los diagramas de probabilidad acumulativa de fractura en función del número de ciclos. Con microscopía electrónica de barrido se observó que el mecanismo de fractura es diferente para cada tipo de muestras. Aquellas de pasta pura de cemento compactada terminaron su ciclo de vida en forma catastrófica, mientras que aquellas con fibra presentaron un comportamiento seudodúctil sin falla catastrófica. Se discuten los resultados y se comparan con otros obtenidos por choque térmico y con la teoría de fragilidad interfacial, así como con la teoría estadística del tiempo de fractura para materiales base cemento sometidos a carga ciclíca. En el caso del choque térmico las microfisuras se generan en la interface matriz-fibra las que actúan simultáneamente como emisoras y bloqueadoras de grietas, mientras que esto no ocurre en el caso de fatiga mecánica.

\begin{abstract}
$S U M M A R Y$
This paper presents the mechanical behaviour of a compacted composite formed by short ductile copper fibres randomly distributed in portland cement matrix. The samples, a half with fibres and the other without them, were subjected to compression fatigue. So, 1 hertz and the value of stress corresponding to the $1 \%$ of the probability of fracture by gradual load were used. Diagrams of cumulative probability of fracture against cycles are obtained for both types of samples. Scanning electron microscopy shows that the mechanisms of fracture are different in each case. Samples of compacted neat-cement paste finish their life with a catastrophic fracture whereas samples of composite behave like a pseudoductile material devoid of catastrophic failure. The results are discussed and compared with the ones obtained by thermal shock and by the interface brittleness theory, as well as with the statistical theory of time-dependent fracture for cementitious materials subjected to cyclic loading. So, in the thermal shock microcracks are generated in the interface matrix-fibre which simultaneously act as emmitings and sumps of cracks whereas this does not occur in mechanical fatigue.
\end{abstract}

\section{INTRODUCCIÓN}

En general en la fabricación de fibrocementos se emplean fibras metálicas incluídas las fibras de acero ya que los coeficientes de expansión de estas fibras y el cemento son similares. Esta propiedad es importante cuando el porcentaje de fibras es elevado, pero cuando este contenido es muy pequeño dicha propiedad carece de

\section{INTRODUCTION}

In general, fibrocement using metallic fibres includes steel fibres because the expansion coefficients of both materials are similar. This property is important when the fibre percentage is large, but when this content is very small this property becomes unimportant. The last of our research works were based on the main idea that, 
importancia. El último de nuestros trabajos de investigación estaba basado en la idea que, dado que los coeficientes de expansión de las fibras de cobre y el cemento son diferentes, alrededor de tales fibras se producen microfisuras capaces de detener las fisuras de fatiga que crecen en el interior de la matriz cuando el material se encuentra sometido a fatiga. Sin embargo ahora, en el presente trabajo, aunque la diferencia entre los coeficientes de expansión de la fibra de cobre y del cemento produzca microfisuras, la fatiga mecánica no activa su producción pero interactúa con ellas de alguna manera. Otra propiedad de las fibras de cobre es su ductilidad la que les permite aceptar una cierta cantidad de deformación sin romperse a causa de las grietas de fatiga. La ductilidad de las fibras de cobre hace que sean más baratas que las de acero y en consecuencia un material compuesto, carente de fractura catastrófica puede emplearse en la manufactura de elementos prefabricados. Tales elementos pueden ser, entre otros, tubos, planchas corrugadas y tejas. Por otra parte, se han hecho algunos trabajos en relación con la resistencia a la corrosión de fibras de cobre embebidas en matrices de cemento.

El primer trabajo fundamental de investigación acerca de este fibrocemento [1] tuvo relación con la decohesión en la interface fibra de cobre-cemento, seguido por la teoría estadística de fractura de un compuesto unidireccional formado por fibras cortas dúctiles [2]. El primer trabajo proporcionó los elementos necesarios para producir el compuesto fibra de cobre cemento compactado [3], así el porcentaje óptimo de fibra y su longitud óptima se obtuvieron. Usando la teoría estadística de fractura se determinó la probabilidad acumulativa de fractura, y nuestra teoría respecto de la fatiga fue verificada posteriormente [4]. La microscopía electrónica de la matriz de cemento que rodeaba la fibra fue realizada por Kittl y Díaz [5]. Se estudió la fatiga térmica del compuesto asbesto cemento y se comparó con el compuesto fibra de cobre cemento [6]. La compatibilidad entre las fibras de cobre y la matriz de cemento pudo ser mejorada mediante una corrosión controlada $[7,8]$ que ejerció una acción directa sobre la interface cobre-cemento. Recientemente Kittl, Díaz, Alvarez y Aldunate [9] estudiaron el mejoramiento de las propiedades mecánicas de tejas confeccionadas con el fibrocemento compactado.

\section{PROCEDIMIENTO EXPERIMENTAL}

Fibras cortas de cobre de $0,00016 \mathrm{~m}$ de diámetro y $0,0018 \mathrm{~m}$ de longitud se distribuyeron aleatoriamente en una matriz de cemento portland owing to the circumstance that copper-fibre expansion coefficient differs from that of cement, around such fibres there are produced microcracks able to stop fatigue fissures growing within the matrix when the material is subjected to fatigue. But now, in the present work, although the difference of expansion coefficient between the copper-fibre and the cement produces microcracks, the mechanical fatigue is not going to produce them, but it is going to interact with them of some way. Another property of copper fibres is that their ductility allows them to undergo a certain amount of deformation without breaking at fatigue cracks. Copper fibre ductility makes them cheaper than steel fibres and thus a composite devoid of catastrophic failure can be made for manufacturing prefabricated elements. Such elements may be piping, corrugated plates, tiles and the like. In addition, some investigation work was made in connection with corrosion resistance of copper fibres embedded in the cement matrix.

The first fundamental research work about this fibrocement was related to decohesion (1) of the copper-fibre cement interface followed by the complete fracture statistics theory of a short ductile-fibre unidirectional composite (2). That first work supplied the elements required for producing a compacted copperfibre reinforced cement composite (3) and the optimum fibre-weight and the optimum fibre-length were ascertained in this later work. The cumulative probability of fracture was determined using fracture statistics, and our theory regarding fatigue was verified thereafter (4). An electron-microscopy study about the cement matrix surrounding the fibre was studied by Kittl and Diaz (5). Thermal fatigue of asbestos-cement composite was studied and compared with that of copper-fibre cement composite (6). The compatibility between the copper-fibres and the cement matrix can be improved by a controlled corrosion $(7,8)$ as a direct action on the interface copper-cement. The improvement of the mechanical properties in tiles made of compacted fibrocement composite was recently studied by Kittl, Díaz, Alvarez and Aldunate (9).

\section{METHODS}

Short ductile copper fibres of diameter $0.00016 \mathrm{~m}$ and length $0.018 \mathrm{~m}$ were distributed randomly in portland cement devoid of additives. 310 
sin aditivos. Se fabricaron 310 muestras cilíndricas de 0,02 $\mathrm{m}$ de diámetro y $0,03 \mathrm{~m}$ de longitud. La mitad del total de muestras se confeccionaron sin fibras mientras que la otra mitad con ellas. La proporción de fibras usadas en el compuesto fue de un $4 \%$ en peso respecto de la matriz de cemento mientras que la razón agua cemento fue de 0,04. La compactación se efectuó en un molde de acero aplicando una presión de $35 \mathrm{MPa}$. Una vez confeccionadas las muestras se las almacenó en una cámara húmeda durante $24 \mathrm{~h}$ a una temperatura de $295^{\circ} \mathrm{K}$ y posteriormente se las sumergió en agua hasta la saturación. A continuación fueron devueltas nuevamente a la cámara húmeda por 6 dias más. Más tarde, 48 muestras de pasta pura de cemento compactada y 50 muestras del compuesto fibra de cobre-cemento compactado se sometieron a un ensayo de compresión estática el cual permitió obtener los diagramas de probabilidad acumulativa de fractura por aplicación gradual de la carga. De este modo, la carga de fatiga empleada fue aquella carga correspondiente a un $1 \%$ de probabilidad acumulativa de fractura cuando ella se aplicaba gradualmente. Los citados diagramas se muestran en las figuras 1 y 2 para las muestras de pasta pura de cemento compactada y para las muestras del compuesto fibra de cobre-cemento compactado, respectivamente. Finalmente, 107 muestras del compuesto y 105 muestras de pasta pura de cemento se sometieron al ensayo de fatiga por compresión. La configuración experimental consistía en una máquina de fatiga formada por un brazo conectado a una leva rotatoria accionada por un motor. La carga se aplicó introduciendo un peso fijo de $37 \mathrm{~kg}$ en un

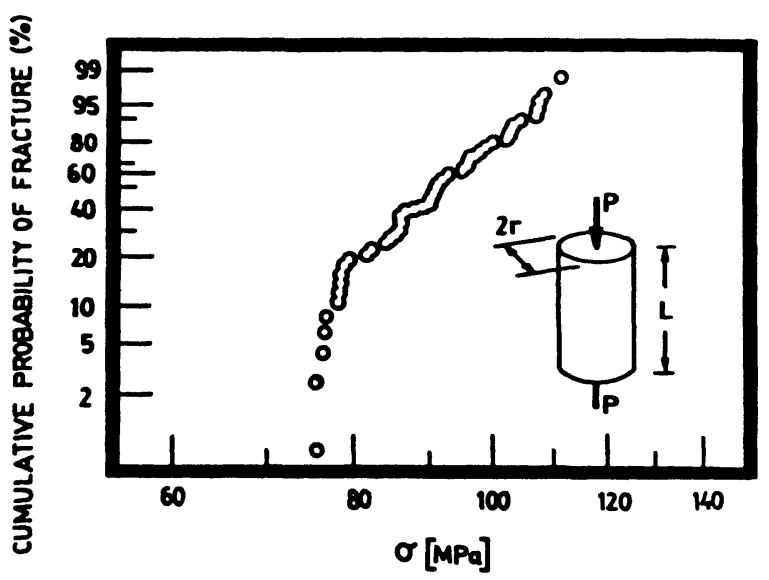

Fig. 1.-Probabilidad acumulativa de fractura por carga gradual para muestras de pasta pura de cemento compactadas.

Fig. 1.-Cumulative probability of fracture by gradual load for samples of compacted neat cement paste. cylindrical samples with diameter $0.02 \mathrm{~m}$ and length $0.03 \mathrm{~m}$ were made. $A$ half of the total samples was made without fibres and the other half with them. For the composite, the proportion of fibres used was $4 \%$ by weight of the cement matrix whereas the water/cement ratio was 0.04 . The compacting was reached by applying $35 \mathrm{MPa}$ pressure into a steel mould. Once made, the test specimens were kept into a moist room for 24 hours at temperature of $295^{\circ} \mathrm{K}$, and after immersed in water until saturation. Afterwards, the samples were placed again in the moist room for six days. Later, 48 samples of compacted neat cement paste and 50 sampjes of copper-fibre cement compact composite were subjected to static compression which allowed to obtain a diagram of cumulative probability of fracture by gradual application of the load. So, the fatigue load was the load corresponding to the $1 \%$ cumulative probability of fracture by applying slow load. The mentioned diagram is shown in figure 1 for samples of compacted neat cement paste and in figure 2 for samples of copper-fibre cement compact composite. Finally, 107 samples of composite and 105 samples of neat cement paste were tested to compression fatigue. The experimental configuration consisted of a fatigue machine constituted of an arm connected to a rotating cam putted in motion by a motor. The load was applied introducing a fixed weight of $37 \mathrm{~kg}$ into a recipient hung of the arm. So then, using a frequency of 1 hertz, the samples were subjected to fatigue until fracture, pointing the number of cycles for the event. The limit number of cycles for a particular specimen was approximately 50.000. A greater number of cycles is not considered because of the long time

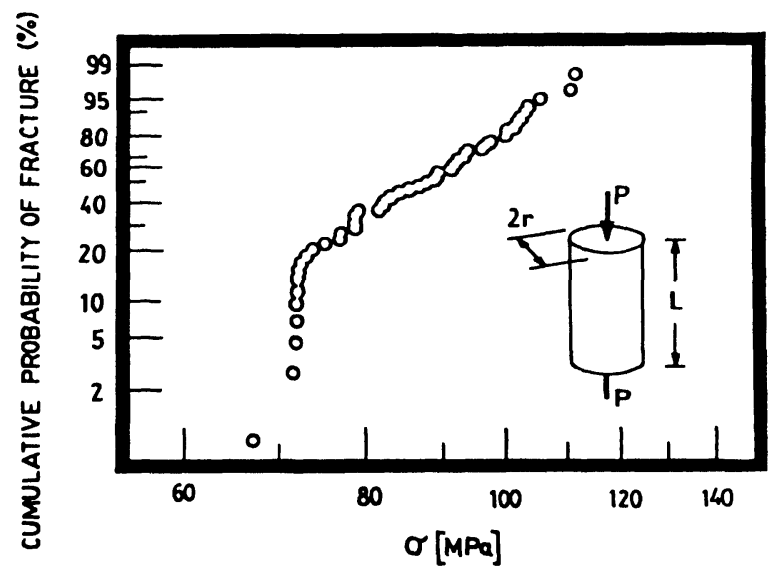

Fig. 2.-Probabilidad acumulativa de fractura por carga gradual para muestras del compuesto fibra de cobre-cemento compactado.

Fig. 2.-Cumulative probability of fracture by gradual load for samples of copperfibre cement compact composite. 
recipiente que colgaba del brazo. Luego, usando una frecuencia de 1 hertz, las muestras se sometieron a fatiga hasta la fractura, registrando el número de ciclos para tal evento. El número límite de ciclos para una muestra en particular fue del orden de 50.000. No se consideró un mayor número de ciclos ya que esto aumentaba el tiempo necesario para completar el ensayo. Se observaron mediante microscopía electrónica de barrido algunas de las muestras con el objeto de dilucidar el mecanismo de fractura.

\section{RESULTADOS Y DISCUSION}

Los datos relativos al número de ciclos requeridos para alcanzar la fractura se ordenaron en forma ascendente. Se determinó la probabilidad acumulativa de fractura usando la fórmula $F(N)=(i-1 / 2) / M$, donde $M$ es el número total de muestras similarmente fabricadas e $i$ es el número de muestras que fallaron a un número de ciclos menor o igual a N. Dicha probabilidad acumulativa de fractura puede ser graficada en función de $\log \mathrm{N}$, el número de ciclos para que ocurra la fractura, lo cual permite obtener el diagrama de la probabilidad acumulativa de fractura por fatiga. La figura 3 corresponde a este diagrama de probabilidad acumulativa del número de ciclos de fatiga hasta la fractura para las muestras de pasta pura de cemento. La figura 4 muestra el mismo diagrama para el caso del compuesto fibra de cobre-cemento compactado.

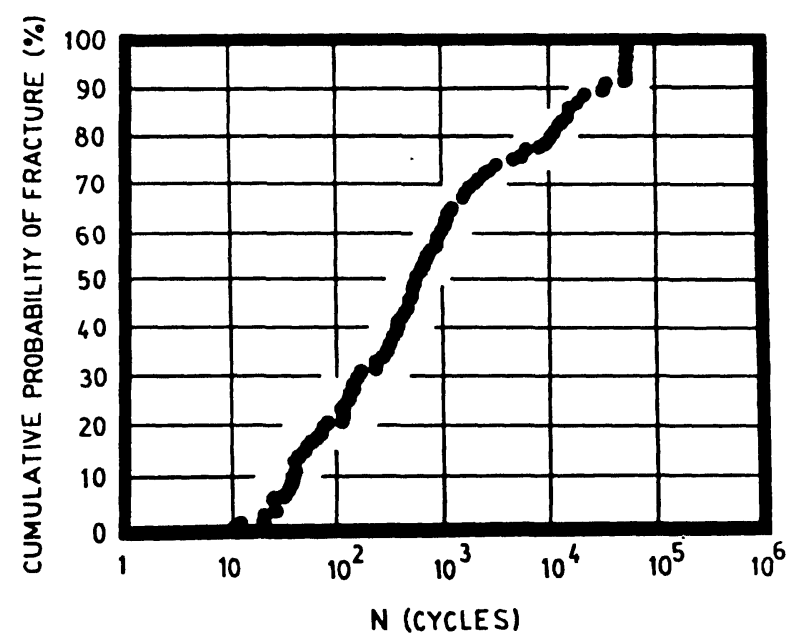

Fig. 3.-Probabilidad acumulativa de ciclos de fatiga para que ocurra la fractura. Muestras de pasta de cemento compactadas.

Fig. 3.-Cumulative probability of fatigue cycles for fracture to occur. Samples of compacted neat cement paste. required to end the test. Some of the samples were observed by scanning electron microscopy so as to elucidate the mechanisms of fracture.

\section{RESULTS AND DISCUSSION}

The data of number of cycles for fracture were ascendantly ranked. Then the cumulative probability of fracture was determined by using the formula $F(N)=(i-1 / 2) / M$, where $M$ is the total number of similar samples tested and $i$ is the number of samples that failed at number of cycles at most equal to $N$. This cumulative probability can be plotted against $\log N$, number of cycles for fracture to occur, which allows to obtain a cumulative probability of fatigue fracture diagram. Figure 3 corresponds to this diagram of cumujative probability of fatigue cycles for fracture for the samples of neat cement paste. Likewise, figure 4 shows the said diagram for the samples of copper-fibre cement compact composite.

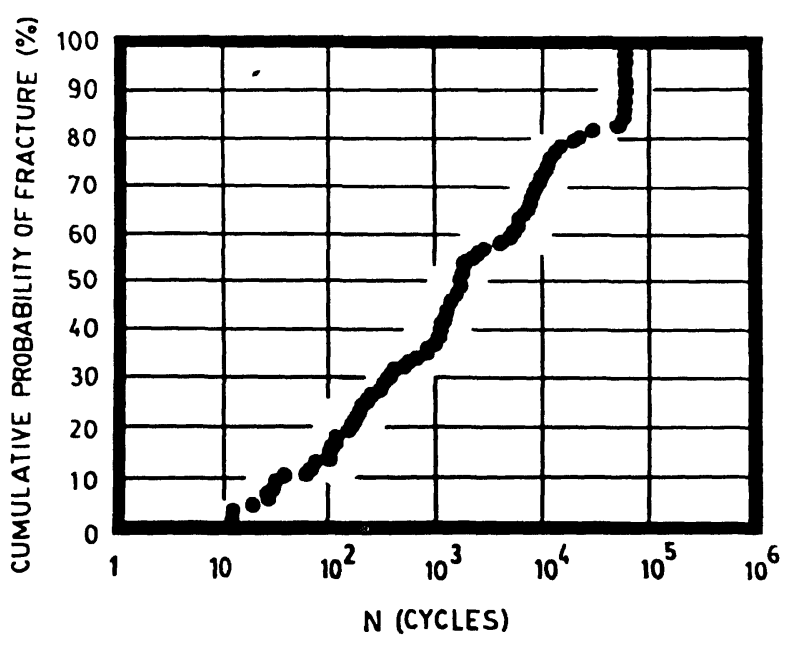

Fig. 4.-Probabilidad acumulativa de ciclos de fatiga para que ocurra la fractura. Muestras del compuesto fibra de cobre-cemento compactado.

Fig. 4.-Cumulative probability of fatigue cycles for fracture to occur. Samples of copper-fibre cement compact composite. 
A fin de interpretar estos diagramas, sea [10]:

$$
\xi(\sigma)=\ln \frac{1}{1-F(\sigma)}=\frac{1}{V_{0}} \int_{V} \phi_{V}[\sigma(r)] d V
$$

la función de Evans, donde $\mathrm{V}$ es el volumen, $\mathrm{V}_{\mathrm{o}}$ es la unidad de volumen $\sigma(r) \leqq \sigma$ es el campo de tensiones, $\sigma$ es la tensión máxima, $r$ es el vector posición $Y \phi_{v}$ es la función riesgo específico de fractura volumétrica de Weibull. La ecuación (1) puede transformarse fácilmente a: the Evans' function, where $V$ is the volume, $V_{0}$ is the unit volume $\sigma(r) \leqq \sigma$ is the stress field, $\sigma$ is the maximum stress, $r$ is the position vector and $\phi_{v}$ is the function of specific risk of volume fracture of Weibull. The eqn (1) can be easily transformed into:

$$
\begin{gathered}
\xi(\sigma)=\frac{1}{V_{0}} \int_{S} \phi_{V}[\sigma(r)] d S \delta+\frac{1}{V_{0}} \int_{V-\Delta V} \phi_{V}[\sigma(r)] d V \\
\Delta V=\int_{S} d S \delta<V
\end{gathered}
$$

donde $S$ es la superficie que limita la interface dúctil-frágil y $S_{0}$ es la unidad de superficie. Introduciendo: where $S$ is the surface limiting the ductile-brittle interface and $S_{0}$ is the unit surface. Introducing

$$
\phi_{S}(\sigma)=\phi_{V}(\sigma) \frac{\delta}{L}
$$

lo cual nos permite obtener la función riesgo específico de fractura superficial: this allow us to obtain the specific-risk of surface fracture function:

$$
\xi(\sigma)=\frac{1}{S_{0}} \int_{S} \phi_{S}[\sigma(r)] d S+\frac{1}{V_{0}} \int_{V} \phi_{V}[\sigma(r)] d V
$$

lo que permite explicar los gráficos de las figuras 1 y 2 , donde la escala es $\ln \xi(\sigma)$ versus $\ln \sigma$ y la función de Weibull admite una tensión $\sigma_{L}$, por debajo de la cual no hay fractura. which allows to explain the graphics of figures 1 and 2, where the scale is $\ln \xi(\sigma)$ against In $\sigma$ and the Weibull function admits a stress $\sigma_{L}$, under which there is no fracture.

$$
\log \left[\ln \frac{1}{1-F}\right]=\frac{m}{n-2} \log N+\frac{m}{n-2} \log \frac{\sigma_{\max }^{n}}{C_{B} f}\left[\frac{G(n, \zeta)}{(1+\zeta)^{n}}\right](n+1)
$$

donde $\mathrm{n}$ es la constante de París,

$$
\times\left[\frac{m n+n-2}{(n-2)(m+1)}\right]^{(n-2) / m}
$$

$$
\begin{aligned}
& \left.G(n, c)=(1 / t) \int_{0}^{t}(1+c \sin \omega t)\right)^{n} d t \\
& 0<\varsigma=\bar{\sigma} / \sigma_{C}<1, \quad \sigma(t)=\bar{\sigma}+\sigma_{C} \text { sinwt, } \omega=2 \pi / T, \quad t / N=T, \sigma_{\max }=\bar{\sigma}+\sigma_{C}, C_{B}
\end{aligned}
$$

$C_{B}$ es una constante y $f=1 / T$, m es un parámetro de Weibull que depende del Proceso de fabricación del material.
$C_{B}$ is a constant and $f=1 / T, m$ is a Weibull parameter depending on the manufacturing process of the material. 
En la fórmula (5) se puede ver que $F=1-\exp \left(N^{c}\right)$, donde $c$ es una constante, mientras que en los gráficos de las figuras 3 y $4, \mathrm{~F}$ es una función líneal de $\log N$. Por lo tanto, no es posible un diseño probabilístico basado en la fórmula (5) y se tienen que emplear los gráficos de las figuras 3 y 4 , directamente, para tal efecto.

Existe un incremento de performance de un $10 \%$ en las muestras de cemento con fibras. Esto podría no justificar su uso, sin embargo la diferencia está en que para las muestras de pasta pura de cemento la fractura es catastrófica, en tanto que en las muestras de cemento con fibras éstas continúan resistiendo. En el caso de la fatiga por choque térmico, las fisuras se producen en la interface, disminuyendo con esto la adherencia entre las fibras y la matriz. Lo anterior implica una disminución en la resistencia a la fatiga. En el caso de la fatiga mecánica no existe esta producción de fisuras y por lo tanto la interfase cemento-fibra no sufre deterioro. Las muestras rotas a la fatiga continúan con su forma, como se muestra en la figura 5, mientras que en las muestras sin fibras, cuando se las fatiga, no hay propagación de grietas ya que la fractura es catastrófica, como se muestra en la figura 6 . En la figura 7 es posible observar que la superficie de la interface se ha roto de tal modo que algunas partes permanecen adheridas a la fibra, mientras que en la figura 8 se muestra cómo las

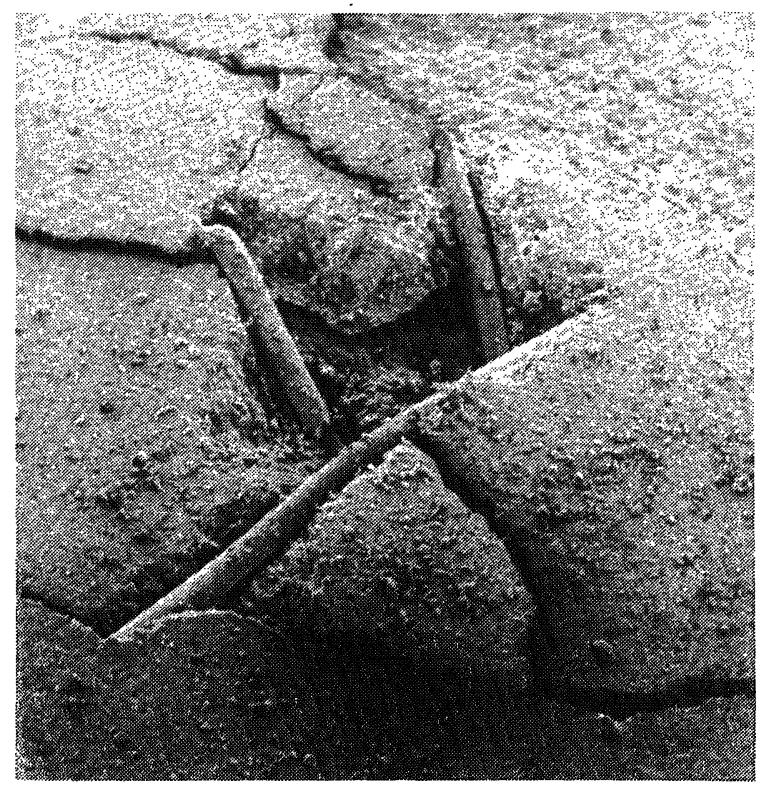

Fig. 5.-Muestra de compuesto fibra de cobre-cemento compactado fracturado por fatiga mecánica. Las partes rotas se mantienen ensambladas (20x).

Fig. 5.-Sample of copper-fibre cement compact composite fractured by mechanical fatigue. The broken parts are maintained assembled (20x).
In formula (5) it can be seen that $F=1-\exp \left(N^{\mathcal{C}}\right)$, where $c$ is a constant, whereas in graphics of figures 3 and 4, $F$ is a linear function of logN. Therefore, it is not possible a probabilistic design based on formula (5) and graphics of figures 3 and 4 have to be directly employed for that purpose.

There is an increase of the performance of $10 \%$ in the samples of cement with fibres. This would not justify its use, but the difference is that in the case of the neat cement paste the sample is broken by catastrophic fracture whereas in cement with fibres the samples continue resisting. In the case of fatigue by thermal shock, fissures are produced in the interface, which makes to decreace the adherence between the fibre and the matrix. This implies a diminution of the fatigue resistance. In the case of mechanical fatigue there no exist this production of fissures and the cement-fibre interface does not suffer damage. The samples broken by fatigue continue with their shape as is shown in figure 5, whereas in the fatigued samples without fibres there is no much propagation of cracks because this is catastrophic, as is shown in figure 6. In the figure 7 , it is observed that the surface of the interface has broken up in such a way that some parts remain sticked to the fibre, whereas in figure 8 is shown as the mentioned fibre holds the broken parts together. So finally, the use of fibrocement

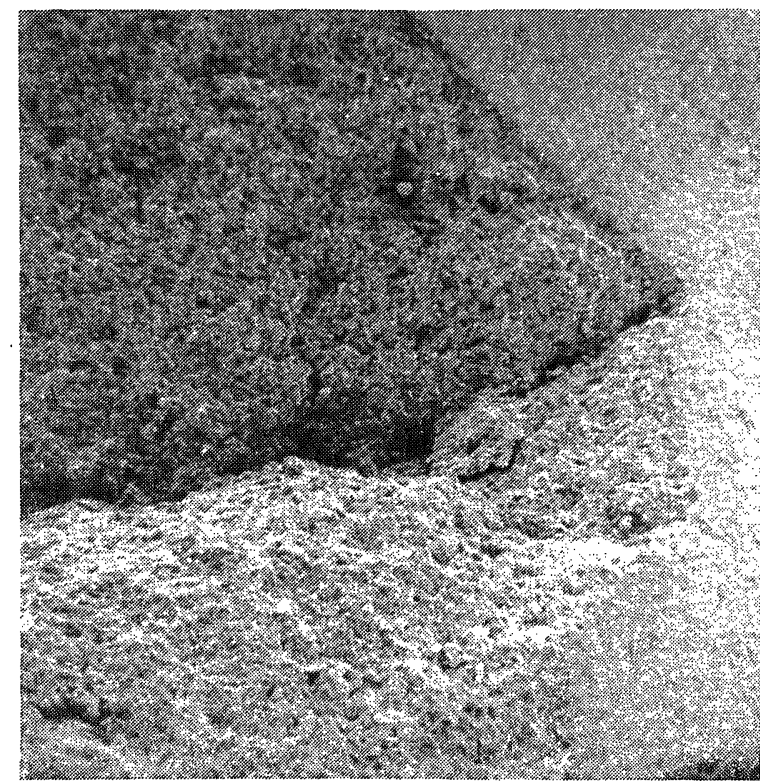

Fig. 6.-Muestra de pasta de cemento compactada fracturada por fatiga mecánica (30x).

Fig. 6. - Sample of compacted neat cement paste fractured by mechanical fatigue (30x). 


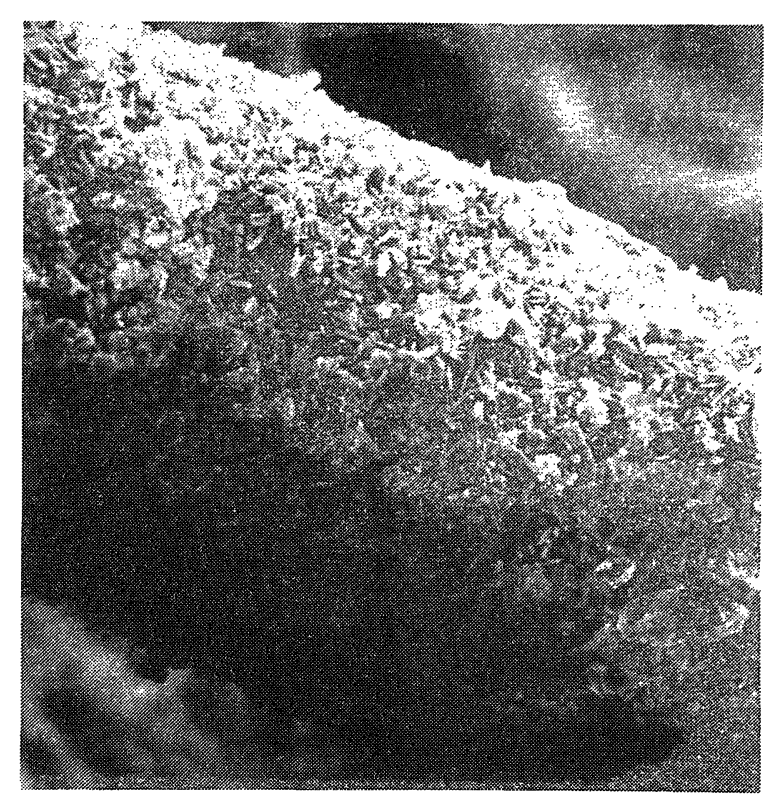

Fig. 7.--Superficie de una fibra de cobre cubierta con cemento hidratado como se muestra después de fracturarse por fatiga mecánica (360x).

Fig. 7.-Surface of a copper-fibre covered with the hidrated cement as is shown after the fracture by mechanical fatigue (360x).

mencionadas fibras mantienen unidas las partes fracturadas. De tal forma finalmente el uso del fibrocemento podría justificarse; en la práctica existe probablemente una superposición de ambas fatigas, mecánica y térmica. En el choque térmico las microfisuras se generan en la interface matriz-fibra, las que actúan simultáneamente como emisoras y bloqueadoras de grietas mientras que esto no ocurre en el caso de la fatiga mecánica.

\section{AGRADECIMIENTOS}

Los autores agradecen al Fondo Nacional de Desarrollo Científico y Tecnológico, FONDECYT, por los proyecto números 1195/91 y 1931056.

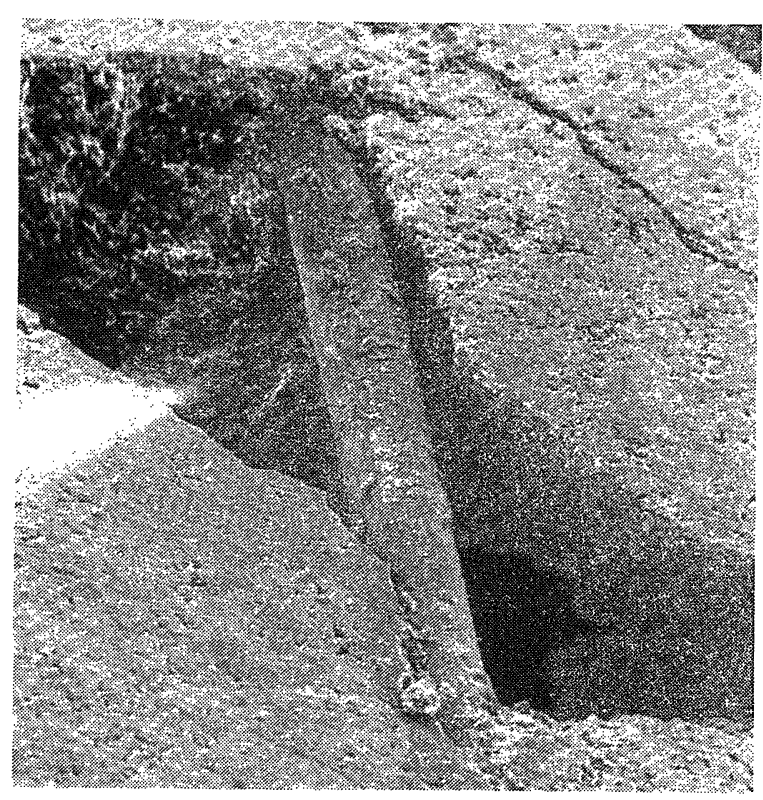

Fig. 8.-Fibra de cobre actuando como sostenedora de partes de una muestra fracturada por fatiga mecánica (72x).

Fig. 8.-A copper-fibre operated as a retainer of parts in the sample fractured by mechanical fatigue $(72 x)$.

composites would be justified; in the practical case there probably is a superposition of both mechanical and thermal fatigue. In the thermal shock microcracks are generated in the interface matrix-fibre which simultaneously act as emmitings and sumps of cracks whereas this does not occur in mechanical fatigue.

\section{ACKNOWLEDGEMENTS}

The authors wish to thank the Fondo Nacional de Desarrollo Científico y Tecnológico, FONDECYT, for Grants N. ${ }^{\circ} 1195 / 91$ and 1931056.

\section{REFERENCIAS}

[1] KITTL, P. and GALLEGUILLOS, E.: Res Mech. Lett., 1 (1981), pp. 115-118.

[2] KITTL, P. and DÍAZ, G.: Res Mech., 13 (1985), pp. 43-54.

[3] KITTL, P., GALLEGUILLOS, E. and DÍAZ, G.: Int. Cem. Comp. Light-Weight Concr., 7 (1985), pp. 193-197.

[4] DÍAZ, G., KITTL, P. and GALLEGUILLOS, E.: Int. Cem. Comp. Light-Weight Concr., 8 (1986), pp. 101-107.

[5] KITTL, P. and DIAZ, G.: 8 th. Int. Congress on the Chemistry of Cement, III (1986), pp. 438-443.

[6] KITTL, P. and DÍAZ, G.: Cem. Concr. Res., 17(1987), pp. 31-36. 
[7] KITTL, P., DÍAZ, G., PERRET, R. and ALVAREZ, N.: Copper 87, Ed. by A. Varschavsky and P. Kittl, Santiago, Chile, 1 (1987) pp. 279-290.

[8] KITTL, P., PERRET, R., ALVAREZ, N. and DÍAZ G.: Cem. Concr. Res., 18 (1988) pp. 539-544.

[9] KITTL, P., DÍAZ, G., ALVAREZ, N. and ALDUNATE R.: Eng. Fract. Mech., 36 (1990), pp. 233-237.

[10] KITTL, P. and DÍAZ, G.: Res Mech., 24 (1988), pp. 99-207.

[11] HU, X., MAI, Y., COTTERELL, B.: J. Mater. Sci., 24 (1989), pp. 3118-3122.

\section{publicaciones del ICCET/CSIC}

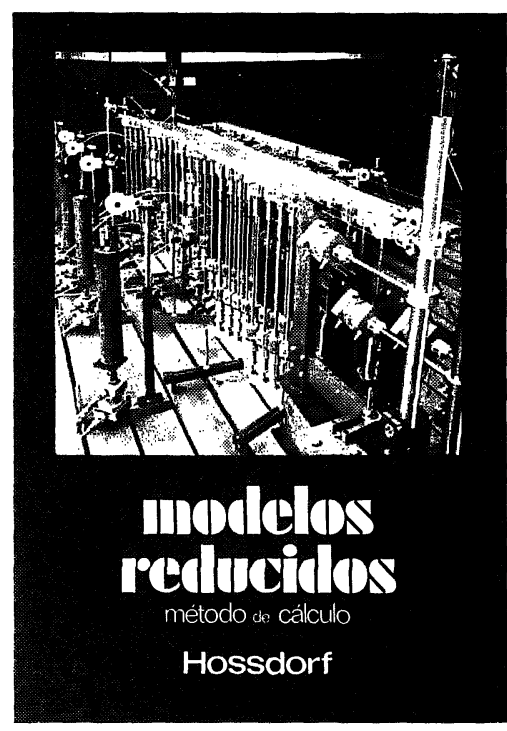

Modelos reducidos. Método de cálculo

H. Hossdorf, Ingeniero Civil

La técnica de los ensayos en modelos reducidos de estructuras sufre hoy dia una decisiva metamorfosis.
Hasta hace poco era un medio más bien de artesanasta hace poco era un medio más bien de artesania, que no siempre era tomado en serio por los académicos teorizantes para comprender el comportaque se acudió las más de las veces, como a un ültimo remedio debido a sus indiscutibles insuficien cias. Sin embargo, en poco tiempo y gracias a su conexión con los ordenadores digitales, se ha transformado en un instrumento cientificamente valioso que no puede quedar a un lado en la práctica diaria del Ingeniero Proyectista.

Un volumen encuadernado en cartoné plastificado con lomo de tela, de $17 \times 24 \mathrm{~cm}$, compuesto de 250 páginas, 158 figuras y fotografias.

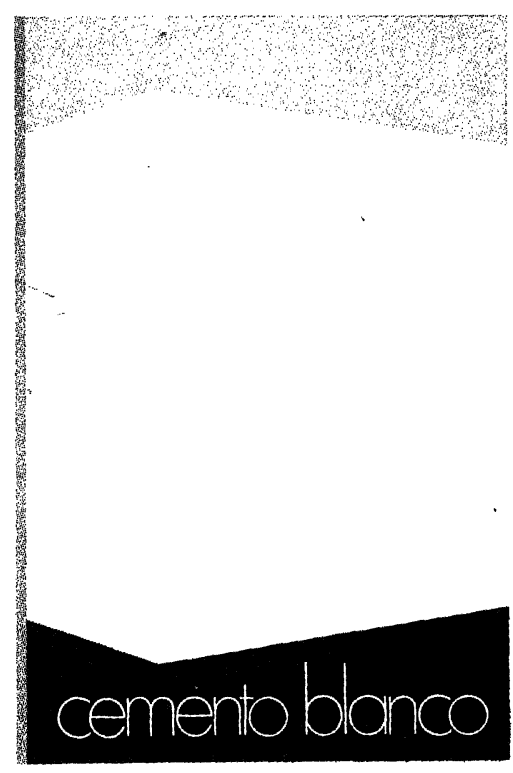

\section{Cemento blanco}

Julián Rezola

Ingeniero Quimico Dipl. I. Q. S.

Sabido es que existe una extensa y documentada bibliografia sobre el cemento gris: en cambio, no puede decirse lo mismo acerca del cemento portland blanco, ya que mis escribs existentes se refien tan de aquél.

El autor nos ofrece sus profundos conocimientos y su larga experiencia tanto en laboratorio como en fabricación.

La parte descriptiva del libro se complementa con gráficos, diagramas y fotografias de gran utilidad, destinados a consegur ta aplicacion apropiz

Un volumen encuadernado ell cartoné policerado, de $17,4 \times 24,3 \mathrm{~cm}$, compuesto de 395 páaginas. numerosas figuras, tablas y ábacos.

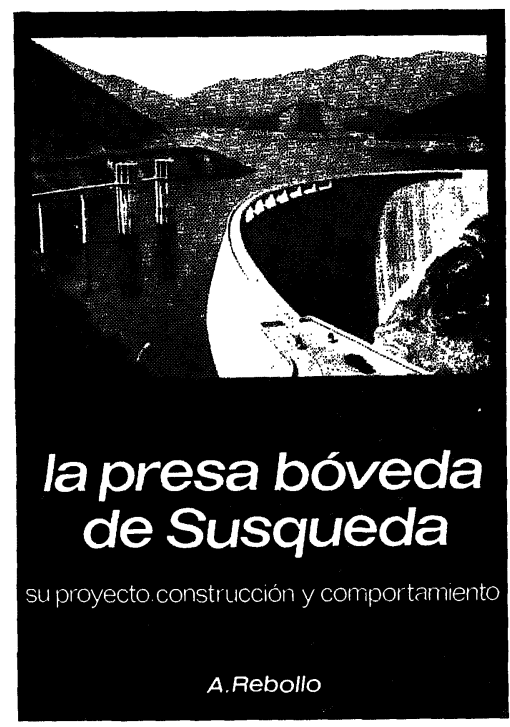

La presa bóveda de Susqueda

A. Rebollo,

Dr. Ingeniero de Caminos

El esfuerzo del constructor de presas se sitúa, por su pretension de perennidad, a contracorriente de las tendencias de la civilizacion actual, caracterizada por to tungible. Pueden evocarse las 10.000 grandes.presas en funcionamiento o en construcción que están envejeciendo $y$ reclaman cos cuidados gerontologicos para mantener y perfeccionar su percios pros, En la medida en que lodas nuevas riessos ecóoicos $y$ a veces, castroficos, de aumentan con el envejecimiento, la las presas es todo un emplazo. Laccion adegia de de Arturo Rebollo en este terreno marca un camino a seguir para todos los que aman su propia obra con la devoción paternal que el ha puesto en Susqueda.

Un volumen encuadernado en cartoné plastificado con lomo de tela de 18 , $24.5 \mathrm{~cm}$ compuesto de 408 páginas, 330 figuras $y$ fotografias $y 39$ tablas. 